\title{
PENGEMBANGAN MODUL PEMBELAJARAN BIOLOGI BERBASIS KEARIFAN LOKAL DI KAWASAN WISATA GOA KREO PADA MATERI EKOSISTEM KELAS X SMA
}

\author{
Atsni Wahyu Lestari' ${ }^{1}$, Lianah ${ }^{2}$, Saifullah Hidayat ${ }^{3}$ \\ 1,2,3, Jurusan Pendidikan Biologi UIN Walisongo Semarang
}

\begin{abstract}
Efforts to develop biological modules based on local wisdom are still not widely used in school learning. One school that has not used biology subject modules based on local wisdom is SMA Negeri 16 Semarang.SMA Negeri 16 Semarang in 2016 has been awarded as Adiwiyata school, a school that is able to apply awareness to the surrounding environment. Therefore, as a school with an awareness of environmental awareness, there needs to be a biology-based learning module based around local wisdom to be applied in the school environment. One effort to realize it, it is necessary to develop a module based on local wisdom ecosystem in the Tourism Area Goa Kreo. From this study is expected to be a source of learning for students, able to provide local wisdom values to learners, as well as efforts to preserve the natural traditions around. This study aims to determine the feasibility and effectiveness of ecosystem material modules that have been developed. This research is conducted by Research and Development method, referring to the Thiagarajan 4-D (define, design, develop, and dessiminate) model. The results of development is very feasible to use delam learning, it is based on the assessment of the quality of modules by material experts with a percentage of $84.54 \%$, module experts with a percentage of $93.34 \%$, biology subject teachers with a percentage of $90.23 \%$, and according to participants' responses Educated with a percentage of $97.2 \%$. Based on the assessment, the module developed is very feasible to use.
\end{abstract}

Keywords: : Module Mining, Goa Kreo, Teaching Materials, Ecosystem Materials 


\begin{abstract}
Abstrak
Upaya pengembangan modul biologi berbasis kearifan lokal masih belum banyak digunakan dalam pembelajaran di sekolah. Salah satu sekolah yang belum menggunakan modul mata pelajaran biologi yang berbasis kearifan lokal ialah SMA Negeri 16 Semarang.SMA Negeri 16 Semarang pada tahun 2016 telah memperoleh penghargaan sebagai sekolah Adiwiyata, yaitu sekolah yang mampu menerapkan kepedulian terhadap lingkungan yang ada di sekitarnya. Oleh karenanya sebagai sekolah berwawasan kepedulian terhadap lingkungan diperlukan adanya modul pembelajaran biologi berbasis kearifan lokal sekitar untuk dapat diterapkan dalam lingkungan sekolah. Salah satu upaya mewujudkan hal tersebut, maka diperlukan pengembangan modul ekosistem berbasis kearifan lokal di Kawasan Wisata Goa Kreo. Dari penelitian ini diharapkan dapat dijadikan sumber belajar peserta didik, mampu memberikan nilai-nilai kearifan lokal kepada peserta didik, serta sebagai upaya menjaga kelestarian tradisi alam sekitar. Penelitian ini bertujuan untuk mengetahui kelayakan modul materi ekosistem yang telah dikembangkan. Penelitian ini dilakukan dengan metode Research and Development, mengacu pada model 4-D (define, design, develop, dan dessiminate) Thiagarajan. Hasil pengembangan sangat layak digunakan delam pembelajaran, hal tersebut berdasarkan pada penilaian kualitas modul oleh ahli materi dengan presentase sebesar $84,54 \%$, ahli modul dengan presentase sebesar $93.34 \%$, guru mata pelajaran biologi dengan presentase sebesar 90,23\%, dan menurut tanggapan peserta didik dengan presentase sebesar 97,2\%. Berdasarkan penilaian tersebut maka modul yang dikembangkan sangat layak untuk digunakan.
\end{abstract}

Kata kunci: Pengambangan Modul, Goa Kreo, Bahan Ajar, Materi

Ekosistem

\title{
PENDAHULUAN
}

Pendidikan merupakan salah satu manifestasi kebudayaan, sejumlah pakar menyatakan bahwa lembaga pendidikan dengan berbagai jenis jenjangnya berperan sebagai pusat pembudayaan (Alwasilah, Suryadi \& Karsono, 2009: 53) yaitu proses untuk menempatkan budaya sebagai visi dan misi proses pendidikan sehingga potensi seseorang untuk belajar dan menyesuaikan pikiran dan sikap terhadap adat, serta sistem norma budayannya berkembang dengan baik (Koenjtaraningrat, 2010: 146). Melalui proses tersebut diharapkan peserta didik mempunyai beberapa karakter yang sesuai dengan nilai-nilai kebudayaan lokal. Nilai-nilai lokal yang terbentuk seharusnya dipertimbangkan untuk memperkaya praktis pendidikan (Halim, 2014: 5).

Keunggulan yang dimiliki oleh masing-masing daerah sangat bervariasi. Dengan kebergaman potensi daerah ini pengembangan potensi dan keunggulan daerah perlu mendapatkan perhatian secara khusus bagi pemerintah daerah sehingga anak-anak tidak 
asing dengan daerahnya sendiri. Salah satu keunggulan lokal di Semarang adalah adaya Kwasan Wisata Goa Kreo. Goa Kreo merupakan tempat wisata yang yang terletak di Dukuh Talun Kacang, Desa Kandri, Kecamatan Gunungpati, Semarang. Kawasan wisata ini merupakan salah satu ekosistem perbukitan yang memiliki luas seluruhnya sekitar 20 hektar. Goa Kreo memiliki legenda goa yang dipercaya sebagai petilasan Sunan Kalijaga saat mencari kayu jati untuk membangun Masjid Agung Demak . Ketika itu menurut legenda Sunan Kalijaga bertemu dengan sekawanan kera yang kemudian disuruh menjaga kayu jati tersebut. Kata "Kreo" berasal dari kata Mangreho yang berarti peliharalah atau jagalah. Kata inilah yang kemudian menjadikan goa ini disebut Goa Kreo dan sejak itu kawanan kera yang menghuni kawasan ini dianggap sebagai penunggu (www.seputarsemarang.com, diakses 22 Oktober 2016). Spesies monyet yang menghuni tempat ini adalah monyet ekor panjang (Macaca fascicularis) jumlahnya sekitar 400 ekor (www.goa-wadukjatibarang.blogspot.com, diakses 22 Oktober 2016). Sumber belajar tidak hanya berasal dari guru dan buku atau text book yang bersifat teoritis, tetapi dapat pula diperoleh dari lingkungan sekitar. Hal tersebut sejalan dengan pendapat brahim (2007) yang menyatakan bahwa keberadaan alam sekitar merupakan potensi yang dapat digunakan untuk menunjang aktivitas peserta didik dalam proses pembelajaran. Potensi lokal yang dimaksud ialah kejadian, peristiwa, permasalahan atau fenomena yang terdapat pada lingkungan daerah asal peserta didik (Marlina, 2013).

Keunikan kawasan wisata Goa Kreo selain adanya populasi monyet yang hidup di daerah tersebut juga adanya waduk jatibarang yang dibangun oleh pemerintah. Waduk ini berfungsi sebagai pengendali banjir, menjaga ketersediaan air minum dengan kapasitas 2,4 liter/detik, dan sebagai energi pembangkit listrik sebesar 1,5 megawatt (Kasno, wawancara 20 Oktober 2016).

Masyarakat yang tinggal di sekitar Goa Kreo dikenal sebagai msyarakat Kandri. Kearifan lokal masyarakat Kandri telah membentuk ekosistem yang unik di Goa Kreo. Masyarakat kandri sampai saat ini masih mempertahankan kebiasaan tradisi Nyadran, Nyadran Goa, Nyadran Kubur, Dan Nyadran Kreo. Dengan adanya kawasan ini maka terciptalah wisata alam dan wisata sejarah sebagai objek kajian pendidikan untuk lebih mengenal Goa Kreo sebagai aset wisata yang memiliki nilai-nilai luhur yang terkandung didalamnya.

Keterkaitan isi pembelajaran biologi dengan sumber daya alam yang dimiliki 
kawasan Wisata Goa Kreo serta masyarakat Kandri menjadi nilai yang sangat kuat dalam memperkaya pembendaharaan ilmu biologi berbasis kearifan lokal. Salah satu materi biologi yang dapat digunakan untuk memperpadukan biologi dengan nilai-nilai lokal adalah materi ekotistem. Salah satu upaya untuk menerapkan nilai-nilai kearifan lokal dalam pembelajaran biologi di sekolah adalah dengan melalui pengembangan modul yang berbasis pada kearifan lokal sekitar. Menurut Renal dkk (2017) Modul salah satu bahan ajar yang dibuat semenarik mungkin disusun berdasarkan indikator dan tujuan pembelajaran serta menggunakan bahasa yang mudah dipahami oleh siswa dan digunakan oleh siswa secara mandiri. Upaya pengembangan modul banyak diterapkan dalam pembelajanran sains seperti fisika, biologi dan kimia (Rahmawati, 2015) Upaya pengembangan modul biologi berbasis kearifan lokal masih belum banyak digunakan dalam pembelajaran di sekolah. Salah satu sekolah yang belum menggunakan modul mata pelajaran biologi yang berbasis kearifan lokal ialah SMA Negeri 16 Semarang. upaya mewujudkan hal tersebut, maka diperlukan pengembangan modul ekosistem berbasis kearifan lokal yang ada di wilayah Semarang sangat diperlukan, salah satunya dengan mengangkat judul penelitian "Pengembangan Modul Pembelajaran Biologi Berbasis Kearifan Lokal Di Kawasan Wisata Goa Kreo Pada Materi Ekosistem Kelas X SMA Negeri 16 Semarang”.

\section{METODE PENELITIAN}

Jenis peneitian ini adalah penelitian research and development (R \& D). Penelitian ini menggunakan model pengembangan Thiagarajan 4D yaitu define, design, development, dan disseminate. Tahap define merupakan tahap untuk menetapkan kebutuhan pembelajaran untuk peserta didik (Sugiyono, 2015: 63). Tahap define terdiri dari analisis ujung depan, analisis peserta didik, analisis tugas, analisis konsep, dan perumusan tujuan pembelajaran (Trianto, 2010: 190).

Analisis ujung depan bertujuan untuk menetapkan masalah dasar yang dihadapi sehingga diperoleh pengembangan alternatif yang relevan untuk memecahkan masalah dasar yang dihadapi. Analisis peserta didik bertujuan untuk menetapkan kebutuhan peserta didik terhadappembelajaran sehingga diperoleh hasil pengembangan yang sesuai dengan kebutuhan peserta didik. Analisis tugas bertujuan untuk menetapkan tugas yang sesuai dengan kebutuhan peserta didik. Analisis konsep untuk menetapkan konsep 
produk yang akan dikembangkan. Perumusan tujuan pembelajaran bertujuan untuk menetapkan indikator atau tujuan yang harus dicapai dalam pembelajaran menggunkan produk yang dikembangkan (Trianto, 2010: 190-192).

Tahap design atau tahap perancangan yaitu bertujuan untuk menyiapkan prototipeproduk (Trianto, 2010: 192). Tahap ini terdiri dari menyusun tes acuan, pemilihan modul, pemilihan format.

Penyusunan tes acuan, tes disusun berdasarkan hasil perumusan tujuan pembelajaran. Tes acuan digunakan untuk mengukur hasil belajar siswa. Pemilihan modul yang sesuai dengan tujuan untuk menyampaikan materi. Dan pemilihan format dnegan mengkaji format perangkat yang sudah ada.

Tahap development terdiri dari validasi produk dan hasil uji lapangan. Validator produk terdiri dari satu orang ahli modul, satu orang ahli materi, dan satu orang guru biologi. Uji lapangan dilakukan pada uji lingkup terbatas untuk mengetahui tanggapan peserta didik terhadap produk yang dikembangkan sebelum digunakan dalam lingkup yang lebih luas. Tahap disseminate pada penelitian ini tidak dilakukan.

\section{HASIL DAN PEMBAHASAN}

Jenis data pada penelitian pengembangan adalah data kuantitatif dan data kualitatif, dimana data kuantitatif didapat dari skor angket. Sedangkan data kualitatif didapat dari tanggapan ahli modul, ahli materi serta tanggapan siswa terhadap modul pembelajaran biologi berbasis kearifan lokal di kawasan wisata Goa Kreo pada materi ekosistem kelas X SMA N 16 Semarang.

Berawal dari permasalahan yang dihadapi peserta didik terhadap proses pembelajaran yang kurang inovatif dan kurangnya pemanfaatan kekayaan lokal untuk modul belajar, peserta didik membutuhkan suatu sumber belajar yang berisi pengamatan. Sumber belajar yang dibutuhkan juga harus memudahkan peserta didik dalam memahami materi ajarnya, sehingga diperlukan adanya sumber pembelajaran untuk meningkatkan efektivitas hasil belajar dan pemahaman pada materi ekosistem yang secara tidak langsung juga menambah pemahamannya terhadap kekayaan lokal sekitar tempat tinggalnya sehingga peserta didik akan lebih mudah dalam melestarikan kekayaan lokal tersebut. Hal tersebut sesuai dengan Depag RI (2002) yang mengungkapkan materi pengajaran dipenuhi nilai-nilai bagi pembentukan pribadi, 
namun apabila pengemasan materi tidak sesuai justru akan membuat rasa tidak suka peserta didik dalam pembelajaran.

Berdasarkan analisis masalah yang dihadapi, maka diperlukan modul sebagai alternatif dari pemecahan masalah yang dihadapi. Modul yang mudah dipahami, menyenangkan kreatif dan inovatif dapat menimbulkan semangat dan ketertarikan siswa pada materi ekosistem, hal tersebut selaras dengan penelitian yang dilakukan oleh Reda Taradipa dan Siswandari (2013) bahwa penggunaan kombinasi modul yang sesuai akan meningkatkan minat belajar. Dengan hal ini dikembangkannya modul pembelajaran biologi berbasis kearifan lokal di kawasan wisata Goa Kreo pada materi ekosistem kelas X SMA N 16 Semarang. Modul yang dikembangkan diharapkan mampu memudahkan dalam memahami materi, menambah wawasan terkait kearifan lokal daerahnya, sehingga menyenangkan dalam penggunaannya, memiliki konsep dan sumber yang jelas mampu mencapai tujuan pembelajaran serta dapat digunakan dalam kegiatan praktikum. Perancangan modul dengan karakter tersebut sesuai dengan UU No 20 pasal 40 ayat 2 yang berbunyi " guru dan tenaga kependidikan berkewajiban menciptakan suasana pendidikan yang bermakna, menyenangkan, kreatif, dinamis, dan dialogis" (Kemenag, 2003).

Pada tahap design modul dilakukan beberapa tahapan. Tahapan pertama adalah pemilihan modul, dilakukan dengan pemilihan aplikasi yang digunakan dalam hal ini menggunakan aplikasi Microsoft Publisher 2010 dan Corel Draw X4. Tahapan kedua yang dilakukan adalah pemilihan format, rancangan awal modul serta pembuatan instrumen sebagai alat ukur efektivitas modul pembelajaran biologi berbasis kearifan lokal di kawasan wiata Goa Kreo pada materi ekosistem kelas X SMA N 16 Semarang.

Tahap development merupakan tahap pengembangan modul secara lebih rinci, pada tahap ini modul akan melalui uji validasi oleh para ahli, dan uji lapangan. Hasil validasi pada rancangan awal terlebih dahulu diuji pada pakar ahli sesuai dengan bidang yang berkaitan dengan modul dan materi yang dikembangkan. Ahli materi menyoroti tentang kandungan dan isi modul, sedangkan ahli modul menyoroti tentang tampilan, dan desain modul.

Hasil uji kelayakan oleh pakar ahli terhadap rancangan awal modul terdapat masukan yang disampaikan yaitu Perlu penjelasan bagaimana asal pembuatan piramida makanan (yaitu dari rantai makanan dan jaring-jaring makanan). Perlu penjelasan apa 
itu karbon? (unsur utama penyusun tubuh makhluk hidup), disarankan, gambar tidak berbahasa inggris, Konten lokal dalam modul harus dikaitkan dengan nilai-nilai karakter terkait dengan "Unity of Science", Penilaian harus mengembangkan 3 ranah yaitu kognitif, afektif, dan psikomotorik, KD pada aspek keterampilan juga harus ditampilkan sebagai satu kesatuan dari KD pengetahuan, Referensi atau rujukan pustaka yang belum lengkap. Hasil penilaian ahli materi diperoleh sebesar 84,54\% dengan kategori sangat layak digunakan. Dan hasil penialaian ahli modul sebesar 93,34\% dengan kategori sangat layak digunakan.

Penilaian modul yang dikembangkan selain dari ahli materi dan ahli modul juga berdasarkan penilaian guru mata pelajaran biologi di SMA Negeri 16 Semarang. Masukan yang diberikan oleh guru yaitu dalam modul juga diperlukan adanya kegiatan peserta didik yang di Goa Kreo sehingga materi yang didapat tidak hanya dari modul yang diberikan seperti yang terdapat dalam lampiran 16. Hasil penilaian guru mata pelajaran diperoleh sebesar 90,23\% dengan kategori sangat layak digunakan.

Tahap Development selanjutnya merupakan uji lapangan, penelitian dilakukan uji lapangan lingkup terbatas, dan uji operasional (uji lingkup lebih luas). Uji lapangan lingkup terbatas dilakukan kepada 10 peserta didik. Uji lingkup terbatas menggunakan angket penilaian. Hasil tanggapan peserta didik dapat dilihat pada lampiran 17. Berdasarkan hasil tersebut dapat disimpulkan bahwa modul materi ekosistem yang berbasis pada kearifan lokal di Goa Kreo yang dikembangkan memiliki kriteria sebesar 97,27\% sehingga dapat dikategorikan sangat layak digunakan.

Hasil penelitian yang telah dilakukan menunjukan modul yang dikembangkan dapat dikatakan sangat layak digunakan dalam pembelajaran dan berhasil pada materi ekosistem. Senada dengan penelitian yang dilakukan oleh Prabowo (2016) Pengembangan modul berbasis potensi lokal pada materi ekosistem dilakukan dengan mengikuti prosedur pengembangan Borg \& Gall layak digunakan sebagai sumber belajar materi ekosistem.

\section{SIMPULAN}

Penelitian yang telah dilakukan menunjukan modul yang dikembangkan dapat dikatakan sangat layak digunakan dalam pembelajaran berdasarkan penilaian ahli media, ahli materi, guru biologi, dan peserta didik SMA Negeri 16 Semarang. 


\section{DAFTAR PUSTAKA}

Alwasilah, Suryadi dan karyono. 2009. Etnopedagogi :Landasan Praktek Pendidikan dan Pendidikan Guru. Bandung: Kiblat

Brahim, K. T. 2007. Peningkatan Hasil Belajar Sains Siswa Kelas IV Sekolah Dasar, Melalui Pendekatan Pemanfaatan Sumber Daya Alam Hayati di Lingkungan Sekitar. Jurnal : Pendidikan Penabur. No. 09/ Tahun ke-6 2007. Jakarta: Universitas Negeri Jakarta.

Departemen Pendidikan Nasional. 2003. Undang-undang No. 20 Tahun 2003 Tentang Sistem Pendidikan Nasional. Jakarta: Depdiknas

Halim, Abdul. 2014. Pendidikan Berwawasan Lingkungan Berbasis Nilai Kearifan Lokal (Studi Kasus Ritual "Among Tani" Di Legoksari Tlogomulyo Temanggung). Semarang : LP2M UIN Walisongo Semarang

Koentjaraningrat. 2010. Pengantar Antropologi I. Jakarta :Rineka Cipta

Marlina, R. 2013. Pemanfaatan Lingkungan Lokal dalam Laboratorium Berbasis Inkuiri Terhadap Kerja Ilmiah Mahasiswa Calon Guru Biologi. Jurnal Visi Ilmu Pendidikan, Vol. 10 No. 1, hlm. 1052-1060.

Prabowo, Dytta Lyawati, Nurmiyati dan Maridi. Pengembangan Modul berbasis Potensi Lokal pada Materi Ekosistem sebagai Bahan Ajar di SMAN 1 Tanjungsari, Gunung Kidul. Proceeding Biology Education Conference (ISSN:2528-5742), Vol 13 (1) 2016: 192-195

Rahmawati, Atik. Pengembangan Modul Kimia Dasar Berbasis Multipel Level Representasi Untuk Meningkatkan Kemampuan Berpikir Kritis Mahasiswa. Jurnal Phenomenon vol 5,No.2 76-79.

Renat, Selly Apriani, Novriayanti Eni., Armen. Pengembangan Modul Dilengkapi Peta Konsep dan Gambar pada Materi Keanekaragaman Makhluk Hidup untuk Siswa Kelas VII SMP. Bioeducation Journal Vol 1. No.1. 2354-8363.

Sugiyono. 2012. Metode Penelitian Pendidikan :Pendekatan Kuantitatif, Kualitatif dan $R \& D$. Bandung : Alfabeta.

Sugiyono. 2015. Metode Penelitian Pendidikan :Pendekatan Kuantitatif, Kualitatif dan $R \& D$. Bandung : Alfabeta.

Suherman, Yuyus. 2008. Pengembangan Media Pembelajaran Bagi ABK. Diklat Profesi Guru PLB Wilayah X Jawa Barat Bumi Makmur : Bandung.

Taradipa, Reda. Dan Siswandari. 2013. Pengaruh kombinasi Media Pembelajaran terhadap Minat Belajar Mahasiswa Pada Mata Kuliah Teknologi Pembelajaran akuntansi DI FKIP UNS Tahun 2013. Surakarta : UNS.

Trianto. 2010. Mendesain Model Pembelajaran Inovatif-Progresif. Jakarta: Kencana Prenada Media Group.

Trianto. 2011. Model Pembelajaran Terpadu: Konsep, Strategi, dan Implementasinya dalam Kurikulum Tingkat Satuan Pendidikan. Jakarta: Bumi Aksara

Anonim, KawasanWisata Goa Kreo, http://seputarsemarang.com/ kawasan- wisata-goakreo-3221/. Diakses pada tanggal 22 Oktober 2016 Pukul 23:07 
Anonim, Tentang Goa Kreo, http://goakreo-wadukjatibarang. blogspot.co.id/2016/02/tentang-goa-kreo.html. Diakses pada tanggal 22 Oktober 2016 Pukul 23:16

Mukminan. 2011. Perspektif Teori dan Implementasi Sekolah Berbasis Keunggulan Lokal Pada Seminar Nasional Dengan Tema "Pendidikan Berbasis Keunggulan Lokal Sebagai Model Pendidikan Berkarakter di Era Global". Universitas Samawa Sumbawa Besar :Pekan Ilmiah Mahasiswa se-NTB. http://staff.uny.ac.id/sites/default/files/penelitian/dr-mukminan/ba-

5unsaperspektif-teori-n-implmnts-pbkl-di-samawa.pdf. $\quad$ Diakespadatanggal 10 Oktober 2016 